\title{
Rules on Assisted Reproduction on Slovenia - Collision Between Legislation on Biomedically Assisted Procreation and Regulation Relating to Safety and Quality of Tissues and Cells
}

URBAN VRTAČNIK

\begin{abstract}
Regulatory landscape on assisted reproduction (AR) has changed over the last 20 years in Slovenia. Notwithstanding the fact that in-field legislation (Infertility Treatment and Procedures of Biomedically Assisted Procreation Act - ZZNPOB) has not been amended or derogated since its adoption in 2000, the regulatory framework has been supplemented with legislative acts, implementing EU Directives on safety and quality of tissues and cells used in treatment. Implementation of the latter (also through adoption of Act on Quality and Safety of Human Tissues and Cells for the Purposes of Medical Treatment - ZKVČTC in 2007) has predominantly failed to acknowledge the specifics of assisted reproduction (regulated by ZZNPOB), resulting in regulatory framework which lacks legal certainty and predictability. Article therefore addresses the collision between ZZNPOB and ZKVČTC and proposes solutions de lege ferenda to avoid shortcomings of existing regulation.
\end{abstract}

Keywords: $\bullet$ IVF $\bullet$ Bioethics $・$ Reproductive Tissues and Cells $\bullet$ ZZNPOB and ZKVČTC • Bioethics •

CORRESPONDENCE ADDRESS: Urban Vrtačnik, Law Firm Vrtačnik, Ltd., Ljubljana, Slovenia, e-mail: urban@vrtacnik.si. 
MEDicine, LAW \& SOCIETY

U. Vrtačnik: Rules on Assisted Reproduction on Slovenia - Collision Between

Legislation on Biomedically Assisted Procreation and Regulation Relating to Safety and Quality of Tissues and Cells

\section{Introduction}

The field of assisted reproduction in Slovenia is influenced by numerous acts and regulations. On the one hand, general rules pertaining to the medical system and medical profession shall be applied, e.g. provisions of the Health Services Act (hereinafter: ZZDej); the Medical Practitioners Act (hereinafter: ZDDrs); the Health Care and Health Insurance Act (hereinafter: ZZVZZ); and, the Patients' Rights Act (hereinafter: ZPacP), whereas on the other hand there are certain legislative acts which address or influence specific issues in assisted reproduction (e.g. Infertility Treatment and Procedures of Biomedically Assisted Procreation Act (hereinafter: ZZNPOB); the Act on Quality and Safety of Human Tissues and Cells, for the Purposes of Medical Treatment (hereinafter: ZKVČTC). Additionally, autonomous rules and recommendations of the Slovenian Medical Chamber shall be considered, especially in the fields of medical ethics and bioethics (e.g. Code of Medical Deontology, Code of Medical Ethics), as well as in relation to physician's professional liability (Rules of the Slovenian Medical Chamber Tribunal, followed by the rules of ZZDej). It has been therefore observed that the legislative and regulative landscape in Slovenia is both highly complex and partially incoherent (Vrtačnik 2018; 30-31).

Following the first successful attempts of in vitro fertilization (hereinafter IVF) in the middle of the 1980's (Janežič et al., 2011: 710-718), the Slovenian system of assisted reproduction was established as an example of good clinical practice. Slovenia experienced its first "test-tube" born babies in 1984, following similar births achieved in 1982 in Germany, France, and Austria (Vrtačnik, 2018: 121-184), To date, more than 13.000 children have been born as a consequence of assisted reproductive techniques in Slovenia (Janežič at al., 2011: 710-718, Vrtačnik, 2018: 10). In 1994, being aware of the deficiencies in then existing legislation (Health Measures in Exercising Freedom of Choice in Childbearing Act, hereinafter: ZZUUP), ${ }^{1}$ the Medical Council established the working group for the preparation of the new legislation (Zupančič, 2008: 237). Medical and bioethical experts, legal professionals, as well as theologians were appointed to the working group (Vrtačnik, 2018: 27).

\footnotetext{
${ }^{1}$ ZZUPP has been adopted in 1978 and has not addressed contemporary procedures of assisted reproduction (Zupančič, 2008: 272).
} 


\section{MEDICINE, LAW \& SOCIETY \\ U. Vrtačnik: Rules on Assisted Reproduction on Slovenia - Collision Between Legislation on Biomedically Assisted Procreation and Regulation Relating to Safety

In 2000, following the work of the expert group, the Slovenian Parliament adopted the ZZNPOB as a core piece of legislation in the field of human reproduction. The ZZNPOB has not been significantly amended or challenged before Constitutional Court of Slovenia since its adoption (see also Vrtačnik et al., 2014: 1). In 2001, a referendum vote was held on the ZZNPOB, in particular, on the issue of whether single women or lesbian couples shall be entitled to IVF. The referendum vote did not lead to any legislative changes, since propose amendments were rejected by $72 \%$ majority of present voters. Only a few court disputes (before the Administrative Court and Labour and Social Court) ${ }^{2}$ have arisen as a consequence of implementation of the ZZNPOB (Vrtačnik, 2018: 82-84, 284-288). Therefore, we consider the ZZNPOB as a stable legislation offering a solid legal framework for the issues related to assisted reproduction in Slovenia. Certain changes to the ZZNPOB are proposed, however, due to both the expiry of time and inter-disciplinary development in the field, (see Vrtačnik, 2018: 387-389).

After Slovenia's accession to the European Union, the Slovenian legal system has been strongly influenced by the EU's acquis, which requires the Slovenian legal system to directly enforce or implement certain EU rules. The ZKVČTC was adopted in 2007 as a consequence of the EU directives (especially Directive No. 2004/23/EC of March 31, 2004, Directive No. 2006/17/EC of February 8, 2006 and Directive No. 2006/86/EC of October 24, 2006). The Act Regulating the Obtaining and Transplantation of Human Body Parts for the Purposes of Medical Treatment (hereinafter: ZPPDČT) was enacted in 2015. These legislative enactments (together with extensive bylaws) strive to provide legal protection not only for the quality and safety of tissues and cells (used in human treatment), but also for the technical issues related to traceability, labelling, processing, storing and distributing of human cells and tissues. On the other hand, EU influenced legislation is deficient because it fails to adequately address certain specifics inherent in reproductive medicine, included in the ZZNPOB, while at the same time being compliant with the Convention for the Protection of Human Rights and Dignity of the Human Being with regard to the Application of Biology and Medicine (hereinafter: Oviedo Convention). This mostly relates to restrictions related to manipulation, storage and use of the human gametes and embryos, as well as to certain questions of anonymity, privacy and third-party exclusions related to procedures of assisted reproduction. In the records

\footnotetext{
2 Judgments of Administrative Court of RS, Reg. No. I U 1669/2013 of April 15, 2014 and Reg. No. I U 877/2015 of September 29, 2015; Decisions of Higher Labour and Social Court, Reg. No. Psp 317/2000 of April 17, 2003, Reg. No. Psp 754/2008 of February 26, 2009 and Psp 351/2011 of November 23, 2011. The latter relate to the question of maximum number of cycles reimbursed under compulsory health insurance and reimbursement of expenses for AR treatments, performed abroad.
} 
on legislative procedure, there are no visible signs that legislator undertook any evaluation on how the ZKVČTC (and ZPPDČT) would influence or interfere with provisions of the ZZNPOB. Additionally, supervision under both pieces of legislation (ZZNPOB, ZKVČTC) has been mostly assigned to two different bodies, i.e. the National Commission for Biomedically-Assisted Reproduction (Državna komisija za OBMP) and the Agency for Medicinal Products and Medical Devices of the Republic of Slovenia (Javna agencija Republike Slovenije za zdravila in medicinske pripomočke - JAZMP), which has resulted in additional difficulties in light of clinical practice, especially since the JAZMP is not keen to accept specifics of the ZZNPOB as a part of substantive law under which administrative bodies enforce its competences (Vrtačnik, 2018: 72).

The aim of this article is therefore to demonstrate the differences and collisions between provisions of the ZZNPOB and the ZKVČTC as well as to highlight certain obstacles that arise in clinical practice over the execution of both regulatory regimes. The conclusive part also proposes certain solutions de lege ferenda to avoid inconsistences and to ensure legal certainty and predictability of the regulatory framework. In this respect, a single legislative act is proposed to govern the area of biomedically-assisted reproduction. This can be achieved by amending the ZZNPOB, respecting restrictions related to assisted reproduction, as well as the specifics of (EU influenced) rules on safety and quality of tissues and cells. Further, it will be recommended that the number and contents of the bylaws shall be also adjusted respectively.

\section{Infertility Treatment and Procedures of Biomedically-Assisted Procreation Act (ZZNPOB)}

The ZZNPOB governs medical measures supporting a man and a woman's efforts to conceive a child, thus promoting the exercise of the right to the freedom of childbearing (Article 1 of the ZZNPOB). The legislative text follows the dualism of reproductive medical measures, by defining:

a) infertility treatment as determining the causes of infertility or impaired fertility and removing these causes through expert advice, medicines or surgical procedures (Paragraph 1, Article 3 of the ZZNPOB); and

b) biomedical assistance in procreation as intracorporal and extracorporal (in vitro) fertilization (Article 4 of the ZZNPOB). Medically related storage (taking and storing gametes of an individual who is at medical risk of becoming infertile) is 


\section{MEDICINE, LAW \& SOCIETY \\ U. Vrtačnik: Rules on Assisted Reproduction on Slovenia - Collision Between Legislation on Biomedically Assisted Procreation and Regulation Relating to Safety and Quality of Tissues and Cells}

considered as infertility treatment in this respect (Paragraph 2, Article 3 of the ZZNPOB).

Under the provisions of the ZZNPOB, a wide array of established methods of assisted reproduction (MAR) and related diagnostics are available in Slovenia (COH, IUI, IVF, IVF/ET, PGD). ${ }^{3}$ In the following text, the ZZNPOB regulates:
a) persons eligible to MAR (Articles 5-7 4 );
b) gamete donation (Articles 8-14);
c) entities and individuals entitled to perform MAR (Articles 15-18);
d) National Commission for Biomedically-Assisted Reproduction (Državna komisija za OBMP, Articles 19-21);
e) execution of AR procedures (Articles 22-29);
f) handling with human gametes and (early) embryos (Articles 30-31);
g) storage of human gametes and (early) embryos (Articles 34-37);
h) scientific and research work (Article 38);
i) reporting and records (Articles 39-40);
j) maternity and paternity of AR conceived children (Articles 41-42);
k) penal provisions (Articles 43-46); and
1) final provisions (Articles 46-48).

For the purposes of this article, analysis of Articles 11, 18, 27, 29 and 34-37 of ZZNPOB shall be of utmost importance. In such respect it has to be noted that disposal with human gametes and (early) embryos is restricted. This is also the case with respect to the couples (persons) from which the genetic material originated. AR centres are restricted from handing over gametes or embryos to any third parties (Article 36 of the ZZNPOB). Article 36 , when read together with paragraph 2 , Article 11, which states in pertinent part 'that donor' shall 'hand over' its gametes only to 'a single AR Centre', leads to the conclusion that the ZZNPOB prohibits human gametes from being transferred between AR centres (or being handed to other bodies). This mutatis mutandis also prohibits any export of human gametes and embryos (import is subjected to the rules of origin country and the ZKVČTC; see Sections 3 and 4, below). Any agency or commercial activity related to 'gathering, storing and disposal of gametes and embryos is prohibited' stricti iuris

\footnotetext{
${ }^{3} \mathrm{COH}$ - Controlled Ovarian Stimulation; IUI - Intrauterine Insemination; IVF - In Vitro Fertilization; IVF/ET - In Vitro Fertilization with Embryo Transfer; PGD - Preimplantation Genetic Diagnosis.

${ }^{4}$ Article 7 defines that both paid and unpaid surrogate motherhood is excluded in Slovenia (more see Kraljić, 2015).
} 
(Article 37 of the ZZNPOB). These provisions of the ZZNPOB shall be observed carefully due to the exclusion of certain aspects of the ZKVČTC, which are intended to achieve opposite effects (circulation and traceability of tissues and cells, establishing databases, standardised procedures of import and export, etc., see section 4 below). Additionally, it has to be noted that under Slovenian law the donors of sperm cells and oocytes have full anonymity (Vrtačnik, 2018: 348-354), subject only to very limited exceptions related to medical data in relation to the child, doctor and judicial/administrative bodies (Article 18 of the ZZNPOB). The donation of gametes does not give rise to a legal donor/child relationship (Article 27 of the ZZNPOB) nor does it result in any donor-related establishment of paternity/maternity (Articles 41 and 42 of the ZZNPOB, Articles 133 and 134 of Family Code). These rules are also important for identifying potential collision points between the provisions of the ZZNPOB and the ZKVČTC.

Certain restrictions and conditions included in Articles 31, 33 and 38 of the ZZNPOB follow the provisions of the Oviedo Convention (Articles 12-14, 16 and 18). The Oviedo Convention was adopted through the act of ratification in the Slovenian Parliament (Act Ratifying the Convention for the Protection of Human Rights and Dignity of the Human Being with regard to the Application of Biology and Medicine). Although fully binding, the restrictions cited above reflect recognition on the part of the legislator that regulation in the field of assisted reproduction must be approached prudently and rather restrictively, mostly due to ethical constraints and constitutional (conventional) safeguards related to human dignity and protection of genetic material. It has to be noted, additionally, that the provisions of the ZZNPOB related to scientific research enacted standards, safeguards and restrictions which provide levels of protection that exceed those established under the Oviedo Convention. Namely, according to the Article 38 of the ZZNPOB, protocols on embryonic research shall be (along with evaluation on other conditions that have to be met according to the law) reviewed and approved by the National Commission for Biomedically-Assisted Reproduction (Državna komisija za OBMP) and the National Committee for Medical Ethics (Komisija RS za medicinsko etiko). ${ }^{5}$ The National Committee for Medical Ethics also supervises pending embryonic research after the permissions are granted Therefore double review and single supervision regime is established, which clearly goes above minimal standards of Oviedo Convention. The ZZNPOB also establishes reporting requirements for AR Centres to the National Commission for Biomedically-Assisted Reproduction (Article 40 of the ZZNPOB). The

\footnotetext{
${ }^{5}$ Acting as national medical ethics committee (NMEC).
} 


\section{MEDICINE, LAW \& SOCIETY \\ U. Vrtačnik: Rules on Assisted Reproduction on Slovenia - Collision Between Legislation on Biomedically Assisted Procreation and Regulation Relating to Safety and Quality of Tissues and Cells}

ZZNPOB establishes a maximum period of five years in which human gametes and early embryos may be stored (in a AR Centre holding special permission for such storage, Paragraph 1 Article 35 of ZZNPOB). The National Commission for BiomedicallyAssisted Reproduction has the authority to prolong this storage period for a maximum period of an additional five years (Paragraph 2, Article 35 of ZZNPOB). Data relating to AR procedures shall be stored for a maximum 50 years (Paragraph 3, Article 39 of the ZZNPOB).

Following the framework of the ZZNPOB, the Minister of Health delivered specific bylaws to govern technical issues related to infertility treatments and procedures of biomedically-assisted procreation, namely:

a) Rules on the structure and content of the report on the methods used in biomedically-assisted procreation;

b) Rules on the forms of the reproductive cell donor's consent in writing; and

c) Rules on the content and format of the biomedically-assisted procreation consent form.

It has been noted to date that entireprovisions of the said bylaws have not been followed in practice since AR Centres have adopted their own reporting policies and forms, partially dependent on the provisions of the ZKVČTC and partially following reporting policies established by the European Society for Human Reproduction and Embryology (ESHRE) (Vrtačnik, 2018: 109-111). This area of regulation therefore requires reformation in the near future.

\section{Act on Quality and Safety of Human Tissues and Cells, for the Purposes of Medical Treatment (ZKVČTC)}

The ZKVČTC governs 'standards of quality and safety of human tissues and cells' (used in medical treatment) to ensure 'high standards of healthcare in the Republic of Slovenia' (Article 1 of the ZKVČTC). The ZKVČTC aims not only to protect the constitutional rights to healthcare and a heathy living environment (Articles 51 and 72 of the Slovenian Constitution), but also addresses the 'protection of human dignity and physical integrity' (Articles 34 and 35 of the Slovenian Constitution; also Vrtačnik, 2018: 57). Within its corpus iuris, the ZKVČTC regulates the 'donation, procurement, testing, processing, preservation, storage and distribution of human tissues and cells intended' for human 
applications and of manufactured products derived from human tissues and cells intended for human applications (Article 2 of the ZKVČTC).

Irrespective of the fact that the ZKVČTC (in Article 2) stipulates that the 'donation, gathering, storage and use of the reproductive cells' are subjected to regulation under the ZZNPOB (which could easily lead to the wrongful conclusion that said provisions entirely exclude application of the ZKVČTC in this field), it can be acknowledged (by the means of practical and historical regulatory analysis - Vrtačnik, 2018: 58) that unless being individually excluded on the basis of the lex specialis rule both the provisions of the ZKVČTC and the ZZNPOB apply. Therefore, every provision of the ZKVČTC must be evaluated to determine whether and to what extent it shall be applied in situations involving biomedically-assisted reproduction. The ZKVČTC will mostly likely not apply to cases in which for substantive, technical or structural reasons, its provisions are incompatible either with specific regulations contained in the ZZNPOB or are at odds with its intended purposes and aims.

In the following text, the ZKVČTC regulates:

a) obligations of authorized bodies (including granting permissions, supervision, traceability of human tissues and cells, import, export and disposal of tissues and cells, establishing and maintaining registries to track same, and reporting Articles 6-12);

b) data protection (including rules on registries of data and defining obligations to report to the central registry kept by Slovenia-transplant - Articles 13-19);

c) selection, evaluation and procurement of tissues and cells (Article 20); d) ensuring quality and safety of tissues and cells (including rules on donor records, persons responsible, personnel, reception, processing, storing, labelling, documenting, packaging and distributing tissues and cells, providing information and giving consent, defining relations between tissue establishment and third parties - Articles 21-33);

d) notification of serious adverse events and reactions - cell and tissue vigilance (Article 34);

e) exchange of information and reporting (Articles 35 and 36);

f) supervision on execution of ZKVČTC provisions (Articles 37 and 38); and

g) penal and final provisions (Articles 39-41). 
The contents of the ZKVČTC predominantly follows the structure and the wording of the EU Directive No. 2004/23/EC of March 31, 2004 (OJ 102/48).

For the purposes of assisted reproduction, of significant importance are the provisions on traceability (Article 10), keeping records (Articles 12, 16, 17, 18 and 22), labelling, processing and storing (Articles 10 and 28), as well as the majority of the provisions related to quality and safety of tissues and cells (Articles 21-33). Paragraph 1, Article 10 of the ZKVČTC, for example, stipulates that all of the tissues and cells used in the territory of Slovenia shall be followed and traced from the donor to the end user and vice versa. Every establishment dealing with tissues and cells shall adopt policies respecting the identification of donors, tissue and cells and related concoctions (Paragraph 2, Article 10). Paragraph 3 Article 10) mandates certain labelling requirements as a component of this process. Additionally, these basic legislative provisions are supplemented with bylaws related to labelling, documenting and packaging (Article 28 of the ZKVČTC). These provisions quite obviously are of great importance in relation to procedures of biomedically-assisted reproduction, since any errors in either the identification, labelling and/or using of human gametes and embryos can lead to grave consequences (e.g. unintentionally fertilizing the woman's oocyte with the semen not belonging to the woman's husband or partner, using donor gametes which should not be used in relation to certain couples due to medical or ethical constraints, proceeding with an embryo transfer using a wrong embryo, etc.) Those failures may not only result in wrongful (anticonventional, unlawful or unethical) consequences, they can also severely harm the dignity and other protected aspects of both the private and family life of the involved individuals (Vrtačnik, 2018: 61-62). Within the rules on quality and safety, the most important provisions are dedicated to the designation of quality policy (which shall follow European standards on Good Manufacturing Practices - GMP; Good Clinical Practices GCP and Good Laboratory Practices - GLP, Paragraph 1, Article 21 of the ZKVČTC), mandating that every tissue establishment shall also adopt 'standard operational procedures' (SOP's), working guidelines, manuals, reporting forms and shall keep specific information on the end-use of human tissues and cells (Paragraph 3, Article 21 of ZKVČTC). Every tissue establishment must also appoint a 'person responsible' (PA), who in turn maintains formal obligations and liabilities towards the applicable regulatory and supervisory bodies (mainly the JAZMP, and Article 23 of the ZKVČTC). The personnel at each establishment should be trained following a regime of regular, frequent and appropriate vocal formation (Article 24 of the ZKVČTC). There is also a vast array of records which shall be kept by tissue establishment (Articles 16, 17, 18 and 22 of the ZKBČTC). Unfortunately, however, these extensive recordkeeping obligations (in which 
certain data is multiplicated as a consequence of different legal grounds applicable and AR centres holding different features, see Section 4, below), are not necessarily compatible with the system of assisted reproduction, which predominantly requires simple, reliable and confidential records (see Section 4, below). Storing of data is required for a minimum of 30 years, with no maximum applicable (Paragraph 5, Article 21 of the ZZNPOB).

There were more than fifteen bylaws (Rules) adopted along with the provisions of the ZKVČTC and the ZPPDČT, defining the procedures, operational standards, technical and other instrumental issues related to the use of tissues and cells (or parts of the human body) for medical treatment. The most important bylaws, having impact on the field of assisted reproduction include:

a) Rules on the conditions for granting licences to perform the activity of supplying human tissue and cells;

b) Rules on the donation and procurement of human tissues and cells;

c) Rules on the reception, processing, storage, release and distribution of human tissues and cells;

d) Rules on the traceability of human tissues and cells and products as well as products and materials coming into contact with these tissues and cells; and

e) Rules on tissue vigilance.

In terms of the interrelationship between the provisions of the ZZNPOB and the ZKVČTC, having these numerous bylaws not only fail to resolve inconsistencies between the two regulatory systems but instead serve only to foster them. Due to inconsistencies and differences in language between rules adopted at the legislative level and those adopted at the lower regulatory level, and the ensuing confusion caused thereby, the actual rights and obligations for individuals are hardly identifiable. In short, the regulatory framework in question simply is too complex, expansive, and therefore incapable of comprehension. (Vrtačnik, 2018: 113). Additionally, some guidelines and forms deriving from the mentioned bylaws are clearly inapplicable for the purposes of reproductive medicine (e.g. due to the fact that the distinction between 'autologous and allogeneic use of tissues and cells' is mostly inapplicable for the procedures of intracorporal or extracorporal fertilization, see Section 4, below). A proposal to reform this situation (referred to the issues of safety and quality of tissues and cells used in reproductive medicine) is included in Section 5, below). 


\section{MEDICINE, LAW \& SOCIETY \\ U. Vrtačnik: Rules on Assisted Reproduction on Slovenia - Collision Between Legislation on Biomedically Assisted Procreation and Regulation Relating to Safety and Quality of Tissues and Cells}

\section{Collision Between the Two Acts}

First of all, it has to be observed that the ZZNPOB and the ZKVČTC differ in fundamental regulatory concepts and basic terminology. The ZKVČTC does not recognize that AR Centres (as regulated by the ZZNPOB) execute powers of: a) cell and tissue establishments; b) donor centres; and c) users of tissues and cells, unified in a single entity. Consequently, therefore, differentiation per specific categories of entities (as established under Paragraph 2, Article 5 of the ZKVČTC) does not fit (and is therefore difficult to be applied) for AR procedures. Additionally, the ZKVČTC considers all persons from whom tissues and cells are originated as constituting donors, whereas donation under the ZZNPOB only includes third-party donation (i.e. donation where a third-party male or a female gamete is received by the couple undergoing an $A R$ procedure). The fundamental differences under the two regimes has resulted in a significant level of confusion in the overall regulatory scheme, since homologous fertilization is deemed as a donor procedure under provisions of the ZKVČT, whereas, under provisions of the ZZNPOB, it is not regulated within the legislative parts, related to specifics of donation (Articles 8-14) and donor procedures (Articles 24-29). This reveals fundamental obstacles related to the interaction of the two regulatory regimes, i.e. that regulation regarding quality and safety of tissues and cells mostly derive from and refer to transplantation medicine, whereas the specifics of assisted reproduction (in most part) differ from concepts of transplantation (Vrtačnik, 2018: 71-72). Among other things, the ZKVČTC also fails to address any issues related to the procurement of human embryos. This is a serious shortcoming in view of the fact that considering an embryo as a human tissue (which teleologically derives from the provisions of the ZKVČTC) is highly controversial and certainly in collision with theories that grant embryos (and foetuses) certain (human) rights, especially the right to dignity (Vrtačnik, 2018: 338) or even limited protections related to the right to life, being proportional to the level of the embryonic or foetal development (Pattinson, 2014: 353; Kraljić \& Drnovšek, 2016: 183184; Žnidaršič Skubic, 2018: 110). Further, as mentioned in Section 3, the differentiation between the autologous and allogeneic use of tissues and cells (which triggers different obligations per specific ZKVČTC related provisions and regulations) fails to comport with both the field of assisted reproduction and the regulative mechanisms of the ZZNPOB. When providing gametes to be fertilized with the gametes of the spouse or a partner (either inside or outside of the women's body) for the purpose of child conception (the only allowed purpose of AR techniques according to the ZZNPOB), said donor (under ZKVČTC) usually does not pursue his or her own treatment, nor the treatment of a third person (person not belonging to a couple). Namely, according to the ZZNPOB, 
MEDicine, LAW \& SOCIETY

U. Vrtačnik: Rules on Assisted Reproduction on Slovenia - Collision Between

Legislation on Biomedically Assisted Procreation and Regulation Relating to Safety and Quality of Tissues and Cells

biomedically assisted reproduction is not considered to be a medical treatment but rather a medical measure (procedure), which enables a couple to overcome unintentional, undesired childlessness that results deriving from either a known or unknown medical condition. If either member of the couple may be treated for his or her own infertility, such person shall be treated under the measures contained in Article 2 of the ZZNPOB (infertility treatment), before being assisted by the means of the AR procedures (Paragraph 2, Article 5 of the ZZNPOV - subsidiary nature of biomedical assistance in procreation). Further, pursuant to the same definition, the donor (under the ZZNPOB) does not contribute to his or her own health (or medical condition) or to the health (or medical condition) of the third person, but instead to the conception of a child being genetically related with one member of the couple that undergoes the AR procedures. Donor procedures (under the ZZNPOB) are, however, more closely linked to the allogeneic use of tissues and cells (Vrtačnik, 2018: 116). For all of the reasons stated above, harmonization in basic conceptions and terminology of both the ZZNPOB and the ZKVČTV is strongly needed.

Secondly, the ZKVČTC does not observe certain restrictions, deriving from the provisions of the ZZNPOB. This mostly refers to the prohibition of delivery of human gametes or embryos to any third person and special regimes on confidentially and anonymity under the ZZNPOB (see Section 2, above). Therefore, several provisions of the ZKVČTC cannot be applied for the purposes of assisted reproduction or can be applied only with limitations, e.g.:

- obligation on delivering cells and tissues to the tissue and cell establishment (Article 8 of the ZKVČTC, since no delivery to third persons is permitted under the ZZNPOB);

- export (or deployment) of human tissues and cells (Article 11 of the ZKVČTC, for the same reason);

- agreement with third parties for execution of certain stages of AR procedure or for processing gametes and embryos (Article 33 of the ZKVČTC, since no third party can provide any services related to AR procedures in which human gametes and embryos are used - this would de facto violate the prohibition of third-party delivery under the ZZNPOB);

- distribution of tissues and cells (Article 29 of the ZKVČTC) and reception of third parties (Article 25 of the ZKVČTVC, except for the couples undergoing AR procedures); 
U. Vrtačnik: Rules on Assisted Reproduction on Slovenia - Collision Between Legislation on Biomedically Assisted Procreation and Regulation Relating to Safety

- reporting to Slovenia-transplant or providing data on AR participants, on tissues and cells required and available for purposes of the unified informational system for transplantation (Articles 8 and 12 of the ZKVČTC, except under restrictions Article 18 of the ZZNPOB, anonymised reporting - providing anonymised data may be therefore plausible, as well as the solution involving a grant authorisation to AR Centre to process certain parts of unified informational without handing over any restricted information, see Vrtačnik, 2018: 63-63);

- donations from minors or persons requiring a representative (Article 14 of the ZKVČTC, since every donor/AR participant under the ZZNPOB shall be of full age and fully competent);

- reception of tissues and cells by minors or incompetent persons (Paragraph 3, Article 31 of the ZZNPOB, since every person undergoing AR procedures must be of full age and competence according to the ZZNPOB); and

- taking tissues and cells from a dead person (Paragraph 2, Article 14 of the ZKVČTC, since posthumous AR procedures or any human fertilization using gametes of a deceased person are strictly prohibited by the ZZNPOB).

Thirdly, there are several parallel systems of reporting and keeping records, required under provisions of the ZZNPOB, the ZKVČTC and related bylaws. Irrespective of the fact that all of these systems apply in tandem, and mostly have binding effects towards AR Centres, a serious drawback is that they also present numerous redundancies and multiplications. Along with the provisions of the Healthcare Databases Act (hereinafter: ZZPPZ), rules under both the ZZNPOB and the ZKVČTC (and their respective bylaws) may impose up do 7 parallel systems of keeping records and up to 3 different systems of reporting (towards different bodies). We do think that (overall regulatory) provisions on reporting and databases need to be much more streamlined and simplified, in order to eliminate the present redundancies and to therefore be more consistent with the purposes of AR and regulatory framework of the ZZNPOB. This recommendation is more than of mere technical importance since certain existing obligations on reporting and providing data (mostly towards Slovenia-transplant) follow regulatory goals (namely broad interchangeability, accessibility of human tissues and cells), which are incompatible with both existing AR procedures and AR related restrictions (see above).

Fourthly, another serious shortcoming of the current situation that is leading to undesired and unnecessary confusion and redundancies is that supervision over execution and implementation of the ZZNPOB and ZKVČTC is spread between different bodies. In terms of the ZZNPOB, most competences are assigned to the National Commission for 
MEDICINE, LAW \& SOCIETY

U. Vrtačnik: Rules on Assisted Reproduction on Slovenia - Collision Between

Legislation on Biomedically Assisted Procreation and Regulation Relating to Safety and Quality of Tissues and Cells

Biomedically-Assisted Reproduction while the violations of the law (misdemeanours regulated by penal provisions of the ZZNPOB), come under the authority of the Health Inspectorate of the Ministry of Health. Under the regulatory framework of the ZKVČTC (and ZPPDČT), competences are distributed between Slovenia-transplant and JAZMP, the latter of which is appointed as licensor and supervisor in relation to the regulatory provisions of the ZKVČTC. As was stated in the introduction (see Section 1, above) the JAZMP is mostly not keen to observe any specifics related to AR procedures or to use any non-ZKVČTC related legislation as a part of material law applicable in supervisory proceedings. In this respect, clear designation (and distribution) of regulatory and supervisory powers, along with a unified regulatory framework (see Section 5, below) is strongly needed to avoid difficulties in practice. We also think that professionals employed by AR Centres should be allowed to work under a system that allows them to predominantly handle challenges related to the bio-medical profession and science, instead (as is the current situation) of being overburdened by administrative tasks related to implementation of in-field regulation and supervisory procedures. Therefore, certain changes to the regulatory framework are also needed.

Finally, on the other hand, certain positive aspects of the adoption of the ZKVČTC and the ZPPDČT should not be ignored. In particular, the regulations in question implement the EU harmonized system of safety and quality of human tissues and cells, which is more precise and accurate as it derives from the provisions of the ZZNPOB. The provisions of the ZKVČTC, and its related bylaws, are to some extent also more strict and technical, which, to a certain degree, can be recognized as beneficial for the purposes of assisted reproduction. Additionally, harmonization under cell and tissue regulations is not only limited to Slovenian AR Centres, but to all EU entities, dealing with tissues and cells. Harmonization has many benefits, chief among them being it will help to obviate some of the negative aspects of reproductive tourism and also in the context of potential establishment of common EU regulatory framework for assisted reproduction in future. Since any regulation on assisted reproduction must, therefore, inevitably follow standards of safety and quality of tissues and cells (compliant and adjusted to specifics of AR procedures), any future regulatory solution cannot be found in simple derogation of the ZKVČTC for the purposes of assisted reproduction. 


\section{MEDICINE, LAW \& SOCIETY \\ U. Vrtačnik: Rules on Assisted Reproduction on Slovenia - Collision Between Legislation on Biomedically Assisted Procreation and Regulation Relating to Safety and Quality of Tissues and Cells}

\section{Conclusion - Proposals de Lege Ferenda}

The following conclusions are offered tentatively, without the intention to induce any degree of certainty upon which further debate would not be encouraged or needed. Before any legislative proposals are debated and developed, there is an urgent need for the specific issues of assisted reproduction to be addressed interdisciplinary, i.e. within the sciences of philosophy, sociology, medicine, law and social work.

First of all, the ZZNPOB itself does requires some changes (Vrtačnik, 2018, 387-388). Inter alia, we do think that the current restrictions under Articles 36 should be softened to a certain level, with a purpose to guarantee a patient with a right to free choice of medical practitioner, which is otherwise granted under Article 9 of the Slovenian ZPacP. Therefore, we believe that the transferring of gametes between AR Centres shall be made possible, under the following conditions:

a) that formal application is filed from the side of the couple being included in the AR programme;

b) that both the transferring and receiving AR Centres are legally permitted on procurement and storage of reproductive tissues and cells;

c) that both the transferring and receiving AR Centres ensure the same level and standard of safety and quality of reproductive tissues and cells (reciprocity); and

d) that such transfers are permitted by the National Commission for BiomedicallyAssisted Reproduction. Records of both centres shall contain data on such transfers, to ensure the required traceability.

Secondly, we do propose, de lege ferenda, that all of the questions of assisted reproduction should be governed by a single piece of legislation. This may be achieved through a legislative process of amendments to the ZZNPOB. Specifically, the amended ZZNPOB shall include provisions related to infertility treatments and biomedically assisted reproduction, along with all of the basic provisions related to the safety and quality in procurement with human gametes and embryos (translation of EU directives). The latter provisions shall be, however, in line with the specifics of reproductive medicine, to overcome obstacles and collisions, analysed in this article. After such amendments, there remains no need for ZKVČTC to further address any questions of reproductive medicine and the ZZNPOB may therefore act as true lex specialis. 
MEDICINE, LAW \& SOCIETY

U. Vrtačnik: Rules on Assisted Reproduction on Slovenia - Collision Between

Legislation on Biomedically Assisted Procreation and Regulation Relating to Safety and Quality of Tissues and Cells

Thirdly, the amended legislation shall include no more than two (2) bylaws (rules), in order to achieve the desired comprehensiveness, predictability and legal safety of the regulation, in which both the rights and the obligations for stakeholders shall be clearly articulated. One of the bylaws may be dedicated to instrumentalization of the ZZNPOB's provisions related to safety and quality of tissues and cells, whereas the other shall include rules on unified reporting, along with pre-prepared forms of informed consents in AR treatments (consent to homologous AR procedures, consent to heterologous $\mathrm{AR}$ procedures, donor consent - male gametes, donor consent-female gametes). No guidelines or forms, deriving from either the ZKVČTC or the ZPPDČT shall therefore apply.

Lastly, we believe that the new regulatory framework shall include a compulsory provision that will require re-evaluating the legislation after the expiry of a certain period (5-10 years). We make this recommendation because only time and experience with the new regulatory framework will provide a solid basis for evaluating whether additional improvements are needed. Since the field of biomedically assisted reproduction comprises numerous medical, legal and ethical issues, in order to develop regulatory provisions that will be useful in the future it is crucial to both understand and be knowledgeable about how similar regulations have functioned in the past and are functioning in the present. Only well thought out and tested provisions have any true potential for standing the test of time and to be beneficial to humankind.

\section{Acts, Regulations and Court Decisions:}

Act on Quality and Safety of Human Tissues and Cells, for the Purposes of Medical Treatment / Zakon o kakovosti in varnosti človeških tkiv in celic, namenjenih za zdravljenje ZKVČTC, Official Gazette of RS, No. 61/07 w/amendments.

Act Ratifying the Convention for the Protection of Human Rights and Dignity of the Human Being with regard to the Application of Biology and Medicine / Zakon o ratifikaciji Konvencije o varstvu človekovih pravic in dostojanstva človeškega bitja v zvezi z uporabo biologije in medicine, Official Gazette of RS, International treaties, No. 17/98.

Act Regulating the Obtaining and Transplantation of Human Body Parts for the Purposes of Medical Treatment / Zakon o pridobivanju in presaditvi delov človeškega telesa zaradi zdravljenja - ZPPDČT, Official Gazette of RS, No. 56/15.

Code of Medical Ethics / Kodeks zdravniške etike, 2016, www.zdravniskazbornica.si, last accessed, July $31^{\text {st }}, 2019$.

Commission Directive 2006/17/EC of 8 February 2006 implementing Directive 2004/23/EC of the European Parliament and of the Council as regards certain technical requirements for the donation, procurement and testing of human tissues and cells, OJ L 38/40, eurlex.europa.eu, last accessed July 31, 2019. 


\section{MEDICINE, LAW \& SOCIETY \\ U. Vrtačnik: Rules on Assisted Reproduction on Slovenia - Collision Between \\ Legislation on Biomedically Assisted Procreation and Regulation Relating to Safety \\ and Quality of Tissues and Cells}

Commission Directive 2006/86/EC of 24 October 2006 implementing Directive 2004/23/EC of the European Parliament and of the Council as regards traceability requirements, notification of serious adverse reactions and events and certain technical requirements for the coding, processing, preservation, storage and distribution of human tissues and cells, OJ L 294/32, eur-lex.europa.eu, last accessed July 31, 2019.

Decree of Higher Labour and Social Court, Reg. No. Psp 317/2000 of April 17 $7^{\text {th }}$ 2003, www.sodnapraksa.si, last accessed, July $31^{\text {st }}, 2019$.

Directive 2004/23/EC of the European parliament and of the Council of 31 March 2004 on setting standards of quality and safety for the donation, procurement, testing, processing, preservation, storage and distribution of human tissues and cells, OJ L 102/48, eurlex.europa.eu, last accessed July 31, 2019.

Family Code / Družinski zakonik - DZ, Official Gazette of RS, No. 15/17 w/amendments.

Health Care and Health Insurance Act / Zakon o zdravstvenem varstvu in zdravstvenem zavarovanju - ZZVZZ, Official Gazette of RS, No. 9/92 w/amendments.

Health Measures in Exercising Freedom of Choice in Childbearing Act / Zakon o zdravstvenih ukrepih pri uresničevanju pravice do svobodnega odločanja o rojstvu otrok - ZZUUP, Official Gazette of SRS, No. 11/77, 42/86 w/amendments.

Health Services Act / Zakon o zdravstveni dejavnosti - ZZDej, Official Gazette of RS, No. 23/05 w/amendments.

Healthcare Databases Act / Zakon o zbirkah podatkov s področja zdravstvenega varstva - ZZPPZ, Official Gazette of RS, No. 65/00 w/amendments.

Infertility Treatment and Procedures of Biomedically-Assisted Procreation Act / Zakon o zdravljenju neplodnosti in postopkih oploditve z biomedicinsko pomočjo - ZZNPOB, Official Gazette of RS, No. 70/00 w/amendments.

Judgement of Administrative Court of RS, Reg. No. I U 1669/2013 of April 15 ${ }^{\text {th }}, 2014$, www.sodnapraksa.si, last accessed, July $31^{\text {st }}, 2019$.

Judgement of Administrative Court of RS, Reg. No. I U 877/2015 of September 29 ${ }^{\text {th }}, 2015$, www.sodnapraksa.si, last accessed, July $31^{\text {st }}, 2019$.

Judgement of Higher Labour and Social Court, Reg. No. Psp 351/2011 of November $23^{\text {th }}$, 2011, www.sodnapraksa.si, last accessed, July $31^{\text {st }}, 2019$.

Judgement of Higher Labour and Social Court, Reg. No. Psp 754/2008 of February $26^{\text {th }}$, 2009, www.sodnapraksa.si, last accessed, July $31^{\text {st }}, 2019$.

Medical Practitioners Act / Zakon o zdravniški službi - ZZdrS, Official Gazette of RS, No. 72/06 w/amendments.

Patients' Rights Act / Zakon o pacientovih pravicah - ZPacP, Official Gazette of RS, No. 15/08 w/amendments.

Rules of the Slovenian Medical Chamber Tribunal / Pravilnik o organizaciji in delu razsodišča Zdravniške zbornice Slovenije, www.zdravniskazbornica.si, last accessed, July $31^{\text {st }}, 2019$.

Rules on donation and procurement of human tissues and cells / Pravilnik o darovanju in pridobivanju človeških tkiv in celic, Official Gazette of RS, No. 70/08 w/amendments.

Rules on the conditions for granting licences to perform the activity of supplying human tissue and cells / Pravilnik o pogojih za izdajo dovoljenja za opravljanje dejavnosti preskrbe s človeškimi tkivi in celicami, Official Gazette of RS, No. 31/17.

Rules on the content and format of the biomedically-assisted procreation consent form / Pravilnik o obrazcu izjave o privolitvi v postopek oploditve $\mathrm{z}$ biomedicinsko pomočjo, Official Gazette of RS, No. 5/03.

Rules on the forms of the reproductive cell donor's consent in writing / Pravilnik o obrazcih o pisni privolitvi darovalke in darovalca spolnih celic, Official Gazette of RS, No. 5/03. 
MEDICINE, LAW \& SOCIETY

U. Vrtačnik: Rules on Assisted Reproduction on Slovenia - Collision Between

Legislation on Biomedically Assisted Procreation and Regulation Relating to Safety

and Quality of Tissues and Cells

Rules on the reception, processing, storage, release and distribution of human tissues and cells /

Pravilnik o sprejemu, obdelavi, shranjevanju, sprostitvi in razdeljevanju človeških tkiv in celic, Official Gazette of RS, No. 70/08 w/amendments.

Rules on the structure and content of the report on the methods used in biomedically-assisted procreation / Pravilnik o sestavi in vsebini poročila o postopkih oploditve z biomedicinsko pomočjo, Official Gazette of RS, No. 5/03.

Rules on the traceability of human tissues and cells and products as well as products and materials coming into contact with these tissues and cells / Pravilnik o sledljivosti človeških tkiv in celic ter izdelkov in materialov, ki prihajajo v stik s tkivi in celicami, Official Gazette of RS, No. 46/18.;

Rules on tissue vigilance / Pravilnik o histovigilanci, Official Gazette of RS, No. 47/17;

Slovenian Code of Medical Deontology / Kodeks medicinske deontologije Slovenije, 12.12.1992, w/amendments, www.kme-nmec.si, last accessed July 31 ${ }^{\text {st }}, 2019$.;

The Convention for the Protection of Human Rights and Dignity of the Human Being with regard to the Application of Biology and Medicine: Convention on Human Rights and Biomedicine (ETS No. 164), www.coe.int, last accessed July 31, 2019.

\section{References}

Janežič, K., Zupanič Slavec, Z. \& Vrtačnik Bokal, E. (2011) Zunajtelesna oploditev - od zamisli do prvega otroka, Zdravstveni vestnik, 80, pp. 710-718.

Kraljić, S. (2015) Nadomestno materinstvo in varstvo otrokovih koristi Komentar sodbe ESČP v zadevi Paradiso in Campanelli proti Italiji, Lexonomica, 7(1), pp. 77-83, doi: 10.18690/18557147.7.1.77-83(2015).

Kraljić, S. \& Drnovšek, K. (2016) Fetus: biti ali ne biti subjekt - to je sedaj vprašanje = Fetus: to be or not to be a subject - this is now the question, In: Zbornik predavanj = Conference proceedings Mednarodna znanstvena konferenca Raziskovanje in izobraževanje $v$ zdravstveni negi (Maribor: Fakulteta za zdravstvene vede), pp. 182-185.

Pattinson S.D. (2014) Medical Law and Ethics, 4th ed. (London: Sweet \& Maxwell).

Vrtačnik, U., Vrtačnik Bokal, E. \& Devjak, R. (2014) Cummulative delivery rate after providing full reimbursement in vitro fertilization programme: a 6 years survey, Biomed Research International, 2014(ID 850478), pp. 1-8, doi: 10.1155/2014/850478

Vrtačnik, U. (2018) Pravni vidiki biomedicinske pomoči pri spočetju, doktorska disertacija [PhD thesis] (Ljubljana).

Zupančič, K. (2008) Pojasnila k Zakonu o zdravljenju neplodnosti in postopkih oploditve z biomedicinsko pomočjo, In: Zupančič, K., Novak B., Predpisi o zakonski zvezi in družinskih razmerjih (Ljubljana: Uradni list RS).

Žnidaršič Skubic, V. (2018) Civilno medicinsko pravo - izbrane teme (Ljubljana: Uradni list RS). 